\title{
INFORMACJE O WEBINARIACH ZORGANIZOWANYCH w Instytucie Nauk o Polityce i Administracji Katolickiego Uniwersytetu Lubelskiego Jana PawŁa II
}

\section{Konferencja Referenda suwerennościowe w państwach de facto - motywy} i konsekwencje

Dnia 25 września 2020 r. odbyła się konferencja naukowa online (via Zoom) poświęcona unilateralnym referendom suwerennościowym w państwach de facto. Uczestnicy spotkania skupili się na analizie przyczyn i konsekwencji organizacji tego rodzaju przedsięwzięć. Odwoływali się przy tym do przypadków referendów suwerennościowych w Abchazji, Górskim Karabachu, Naddniestrzu, Kurdystanie, Osetii Południowej, Somalilandzie i Tajwanie. Konferencje zorganizował dr hab. Marcin Kosienkowski z Instytutu Nauk o Polityce i Administracji KUL, który dodatkowo wygłosił referat o przyczynach organizacji przez władze naddniestrzańskie w 2006 r. referendum dotyczącego kontynuacji kursu Naddniestrza na niepodległość i stowarzyszenia/ integracji tego państwa de facto z Rosją. W spotkaniu wzięli udział również: dr Micha Germann (University of Bath), dr Tomáš Hoch (University of Ostrava), dr Markus Hoehne (Leipzig University), dr Siergiej Markiedonow (MGIMO University), mgr Kamaran Palani (Salahaddin University-Erbil \& Leiden University) i dr hab. Robert Rajczyk (Uniwersytet Śląski).

\section{Sesje pytania-odpowiedzi poświęcone problematyce konfliktu} naddniestrzańskiego

Dnia 12 października 2020 r. odbyła się online sesja pytań i odpowiedzi (via Zoom) z Alexandru Flenchea, byłym wicepremierem w rządzie Mołdawii, odpowiedzialnym za reintegrację separatystycznego Naddniestrza. Podobna sesja z Niną Szewczuk (Sztanski), byłą minister spraw zagranicznych regionu naddniestrzańskiego, odbyła się 10 czerwca 2020 r. Oba spotkania zostały zorganizowana przez dr. hab. Marcina Kosienkowskiego z Instytutu Nauk o Polityce i Administracji KUL. Wzięli w niej udział polscy badacze i eksperci, zajmujący sie problematyką naddniestrzańską: Kamil Całus (Ośrodek Studiów Wschodnich), prof. Magdalena Dembińska (Uniwersytet Montrealski), dr Piotr Oleksy (Uniwersytet Adama Mickiewicza w Poznaniu) i Jakub Pieńkowski (Polski Instytut Spraw Międzynarodowych). Przedmiotem 
obu spotkań były kwestia uregulowania konfliktu naddniestrzańskiego oraz zjawiska i procesy społeczno-polityczne zachodzące w Naddniestrzu. Rozmowa z przedstawicielami dwóch stron konfliktu pozwoliła uczestnikom spotkań spojrzeć na problem naddniestrzański z szerszej perspektywy i bardziej obiektywnie ocenić zachodzące w Mołdawii wydarzenia.

Marcin Kosienkowski*

* Dr hab. Marcin Kosienkowski-Instytut Nauk o Polityce i Administracji, Katolicki Uniwersytet Lubelski Jana Pawła II, e-mail: marcin.kosienkowski@kul.pl 